\title{
ターボチャージャ用タービン動翼の共振応答特性に関する研究
}

\author{
金子 康智*1, 森 一石 ${ }^{* 2}$ ，恵比寿 幹*3，小川 真司 ${ }^{* 4}$ ，竹下 友祥 ${ }^{* 5}$
}

\section{Study on vibration response characteristics of turbine blade for turbo-charger}

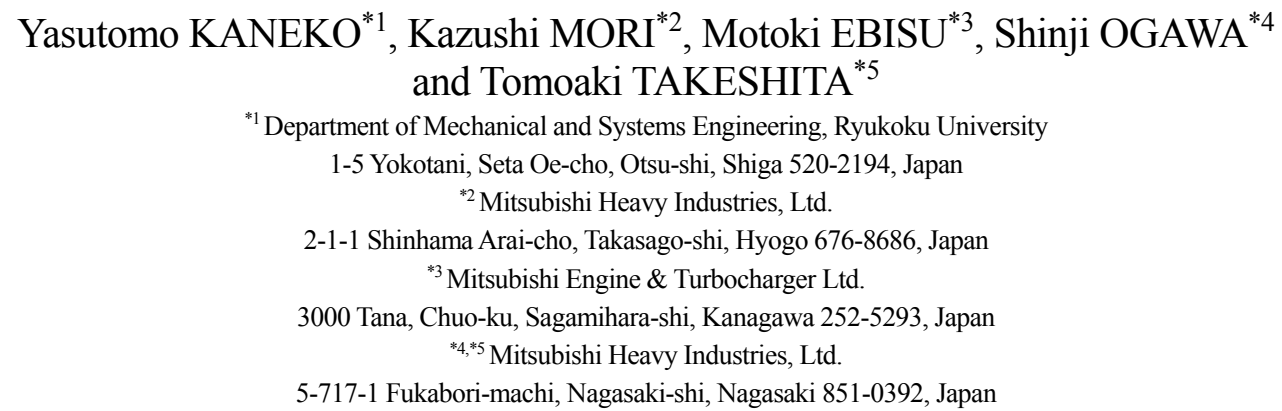

Received: 6 November 2018; Revised: 12 January 2019; Accepted: 31 March 2019

\begin{abstract}
In the mechanical design of a turbine blade for an automotive turbo-charger, it is pointed out that the mistuning effect caused by the difference of the casting condition should be considered. Namely, the difference of the casting condition causes the small variation of Young's modulus of each blade on a turbine wheel. These small variations break the cyclic symmetry, and split the eigenvalue pairs. In the forced response of a mistuned system, the responses of all blades become different, and the response of a certain blade may become extremely large due to splitting of the duplicated eigenvalues and distortion of the vibration modes. In this study, the reduced order model FMM (Fundamental Mistuning Model) is applied to evaluate the resonant response of mistuned system. First, the frequency response analysis of mistuned system is carried out, using both of the FMM and the direct FEM, and the calculated results are compared to confirm the validity of the FMM. Second, the frequency response analysis of mistuned system is carried out using the FMM, the Monte Carlo simulation and the optimal method to examine the effect of various parameters on the maximum response of a mistuned system. In addition, the effect of the intentional mistuning on the reduction of the maximum response is researched using the genetic algorithm.
\end{abstract}

Keywords : Turbomachinery, Forced vibration, Blade, Mistuning, Optimal design

\section{1. 緒言}

エンジンへ空気を過給するターボチャージャは，世界的な排ガス規制対策，燃費改善の有効な手段として成長 を続けているが, 小型大容量化の要求により運転環境は益々厳しさを増している.ターボチャージャの信頼性は, その心臟部であるタービン動翼の信頼性に依存しており，設計段階でタービン動翼の振動特性を正確に予測し， 振動強度を確保寸ることが不可欠になっている（大迫他，2006）。このようなターボチャージャ用タービン動翼の 振動強度設計において考慮す心゙き項目として，鋳造時の鋳造条件の差異により生じるミスチューン効果が指摘さ れている（Hemberger et al., 2013，2014，宮下，2017)。すなわち，鋳造条件の差異により個々の翼のヤング率が 僅かに変動するため, 個々の翼の共振応答に差が現われ，その最大値は全翼の特性が均一なタービン動翼（チュ

No.18-00425 [DOI:10.1299/transjsme.18-00425], J-STAGE Advance Publication date : 9 April, 2019

本論文は，Dynamics and Design Conference 2018 講演論文集(2018), No.431の掲載内容に基づいた論文である.

${ }^{* 1}$ 正員, フェロー，龍谷大学（广520-2194 滋賀県大津市瀬田大江町横谷 1-5)

*2 正員, 三菱重工業 (株) 総合研究所（广676-8686 兵庫県高砂市荒井町新浜 2-1-1）

*3 三菱エンジン\&ターボチャージャ（株）（厂252-5293＼cjkstart神奈川県相模原市中央区田名 3000）

*4三菱重工業（株）総合研究所（广851-0392＼cjkstart長崎県長崎市深堀町 5-717-1）

*5 正員, 三菱重工業（株）総合研究所

E-mail of corresponding author: y_kaneko@rins.ryukoku.ac.jp 
ーン系）よりも増大するということが多くの文献で報告されている.

著者らは，全周の翼枚数が多い軸流のガスタービンや蒸気タービンの翼・ディスク系に対して，FMM

(Fundamental Mistuning Model）やSNM（Subset of Nominal Modes）などの低次元モデルを利用してこのようなミ スチューニング現象を解明してきた（金子他，2013，2017）。本論文では，翼枚数が少ないターボチャージャ用の タービン動翼に対して低次元モデル FMM を利用し，そのミスチューン特性を解析する．具体的には，ターボチ ヤージャ用タービン動翼の共振応答を直接有限要素法で解析した場合と FMM を適用して解析した場合を比較し, 解析法の有効性を検証する. 次に, FMM とモンテカルロ法や最適化手法を組合せてタービン動翼に発生し得る 最大共振応答を予測するとともに，ミスチューン効果に及ぼす減衰や翼枚数の影響を調査する．またターボチャ ージャ用タービン動翼の実用的な振動応答低減手法として，インテンショナルミスチューンの共振応答低減効果 を検討する.

\section{2. 解析方法}

\section{$2 \cdot 1$ FMM によるミスチューン系の固有值解析}

FMM の理論については文献（Feiner and Griffin, 2002, 2003）に詳しく説明されているが，ここでは論文の完結 性のために要点を記述する. FMM では, 翼・ディスク系のモード族が完全に分離しているとき, ミスチューン がある翼・ディスク系の着目するモード族の振動モードを, チューン系の当該モード族の振動モードの重ね合わ せで式（1）のように表す.

$$
\left\{\phi_{r}\right\}=\sum_{m=0}^{N-1} \beta_{r m}\left\{\phi_{m}^{0}\right\}, \quad(r=0, \cdots, N-1)
$$

ここで, $\left\{\phi_{r}\right\}$ はミスチューン系の着目するモード族における $r$ 次の振動モード, $\left\{\phi_{m}^{0}\right\}$ はトラベリングウェーブ モードで表示したチューン系の当該モード族の $m$ 次の振動モードであり， $N$ は全周の翼枚数である. $\beta_{r m}$ はミス チューン系の $r$ 次の振動モードに占めるチューン系の $m$ 次のトラベリングウェーブモードの振幅（以下，TWM の振幅）を表す係数であり, 式（2）の固有值問題を解くことにより求めることができる.

$$
\left[\Lambda^{0}+\hat{A}\right]\left\{\beta_{r}\right\}=\omega_{r}^{2}\left\{\beta_{r}\right\}, \quad\left[\Lambda^{0}\right]=\left[\Omega^{0}\right]^{T}\left[\Omega^{0}\right], \quad \hat{A}=2\left[\Omega^{0}\right][\bar{\Omega}]\left[\Omega^{0}\right]
$$

ここで $\left[\Omega^{0}\right]$ は, チューン系の固有振動数を対角成分にする対角行列であり, チューン系の振動モードをトラベ リングウェーブモードで表示し翼間位相差が増加寸る順に振動モードを並べたとき，これに対応する順に固有振 動数を並ベている. $\omega_{r}$ はミスチューン系の $r$ 次の固有振動数である. [ $\left.\bar{\Omega}\right]$ は, ディスク上の個々の翼の固有振動 数分布の離散フーリエ変換を成分にする行列であり, 式（3）のように表すことができる.

$$
[\bar{\Omega}]=\left[\begin{array}{cccc}
\bar{\omega}_{0} & \bar{\omega}_{1} & \cdots & \bar{\omega}_{N-1} \\
\bar{\omega}_{N-1} & \bar{\omega}_{0} & \cdots & \bar{\omega}_{N-2} \\
\vdots & \vdots & \ddots & \vdots \\
\bar{\omega}_{1} & \bar{\omega}_{2} & \cdots & \bar{\omega}_{0}
\end{array}\right]
$$

$[\bar{\Omega}]$ は循環行列であり, その要素 $\bar{\omega}_{p}(p=0, \cdots, N-1)$ は, 翼単体の固有振動数（着目するモード族の固有振 動数）の周方向の分布を離散フーリエ変換したときの $p$ 番目の成分であり，式（4）で表すことができる.

$$
\bar{\omega}_{p}=\frac{1}{N} \sum_{s=0}^{N-1} \exp \left(i s p \frac{2 \pi}{N}\right) \Delta \omega_{b}^{(s)}
$$

ここで, $\Delta \omega_{b}^{(s)}$ はミスチューンにより生じた $s$ 番目の翼単体の固有振動数の偏差であり, チューン系の翼単体の 固有振動数を $\omega_{b}^{0}$, ミスチューン系の $s$ 番目の翼単体の固有振動数を $\omega_{b}^{(s)}$ とすると, 式 $(5)$ から求めることができ る. 


$$
\Delta \omega_{b}^{(s)}=\frac{\omega_{b}^{(s)}-\omega_{b}^{0}}{\omega_{b}^{0}}
$$

すなわち，FMM でミスチューン系の固有振動数と振動モードを計算するために必要な情報は，着目するモー ド族に関するチューン系の固有振動数 $\left[\Omega^{0}\right]$ ，チューン系の振動モード $\left\{\phi_{m}^{0}\right\}$ ，およびミスチューン系の翼単体の 固有振動数の分布 $\Delta \omega_{b}^{(s)}$ の三つだけである. これらの情報を入力にして式（3）から式（5）を使用して式（2）の 各要素を計算し, 式 (2) の固有值方程式を解く. その結果, ミスチューンがある翼・ディスク系の固有振動数 $\omega_{r}$ と TWM の振幅 $\left\{\beta_{r}\right\}$ が求まるので, TWM の振幅 $\left\{\beta_{r}\right\}$ を式（1）に代入して固有モード $\left\{\phi_{r}\right\} を$ 求める. 式 (2) の係 数行列の次元は $N \times N(N$ :翼枚数 $)$ であり, 自由度を大幅に縮小した固有值方程式を解いて, ミスチューンがある 翼・ディスク系の固有振動数や振動モードを計算することができる. また, FMM の入力として必要になるチュ ーン系の固有振動数 $\left[\Omega^{0}\right]$ やチューン系の振動モード $\left\{\phi_{m}^{0}\right\}$ は, 周期対称法を適用すれば 1 セグメント分だけの自 由度に縮小したモデルで解析できる。

\section{$2 \cdot 2$ ミスチューン系の強制振動解析}

ハーモニック加振力に対するミスチューン系の周波数応答を解析する場合には, 式 (2) に外力項を追加した式 （6）を解析する.

$$
\left[\Lambda^{0}+\hat{A}-\omega^{2}[I]\right]\left\{\beta_{r}\right\}=\left\{F^{w}\right\}
$$

ここで， $\left\{F^{w}\right\}$ は偏流や翼列干渉力のように作動流体との連成を考慮しない非定常力（モーダル外力）の振幅 であり, $\omega$ は加振力の周波数である. 周波数応答を解析寸る場合はチューン系の $r$ 次のモードに対して構造減衰 を導入するため, $\left[\Lambda^{0}\right]$ の要素を式（7）で定義する.

$$
\Lambda_{r, r}^{0}=\left(\omega_{r}^{0}\right)^{2}\left(1+i 2 \varsigma_{r}^{0}\right), \quad(r=1, \cdots, N)
$$

ここで， $\omega_{r}^{0}$ と $\varsigma_{r}^{0}$ はチューン系の $r$ 次のモードの固有振動数と減衰比である. 式（6）から TWM の振幅 が求 まると，物理座標での周波数応答は式（8）から求めることができる.

$$
\{X\}=[E]\left\{\beta_{r}\right\}
$$

行列[E]は物理座標で表した変位とトラベリングウェーブモードで表した変位の座標変換行列であり, 行列 $[E]$ の $k$ 行 $l$ 列の要素 $E_{k, l}$ は式 $(9)$ で表すことができる.

$$
E_{k, l}=\exp \left(i \frac{2 \pi k l}{N}\right),(k, l=0, \cdots, N-1)
$$

\section{3. 解析結果}

\section{$3 \cdot 1$ 低次元モデル FMM の検証}

低次元モデル FMM の有効性を検証するため, ターボチャージャ用タービン動翼の周波数応答解析を行い，有 限要素法で直接解析した結果と比較した. 図 1 に解析に使用したタービン動翼の有限要素モデルと周期対称法で 計算した固有振動数を示す. 図 1 の有限要素モデルの節点数は 1 セグメント当たり約 1 万 4 千節点であり, ター ビン動翼全体（N=9）では, 約 12 万節点である. 図 2 に, 周期対称法で解析した 1 次モード族のタービン動翼の 振動モードを示す. 以下の解析では, タービン動翼の 1 次モード族と偏流との共振応答を解析対象にしており, 加振力のハーモニック数 $(H)$ を 5 , 対数減衰率 $(\delta)$ を 0.01 にしている. FMM の検証解析は, 以下の 2 ケース のミスチューン系について実施した.

Case 1: チューン系に対して\#1 翼の振動数が-2\%, \#3 翼の振動数が+2\%変動するミスチューン系 
Case 2: 個々の翼の固有振動数の変動が正規分布（変動係数 1\%）に従うと仮定し, FMM とモンテカルロ法で 求めたワーストミスチューン系. 寸なわち, 共振応答が最大になるミスチューン系.

有限要素法でミスチューン系の解析を行う場合は，個々のセグメントのヤング率を変えてミスチューン系を作 成し，全周モデルを利用してモーダル法により周波数応答解析を行っている．具体的には，例えばセグメント 3 の振動数を+2\%変化させる場合は, セグメント 3 のヤング率をチューン系のヤング率の $1.02^{2}$ 倍にしている.なお, 有限要素法の解析には汎用有限要素法コードANSYS（六面体ソリッド要素 SOLID185）を利用しており，図 1 の ディスク裏側の軸との結合部を固定している.

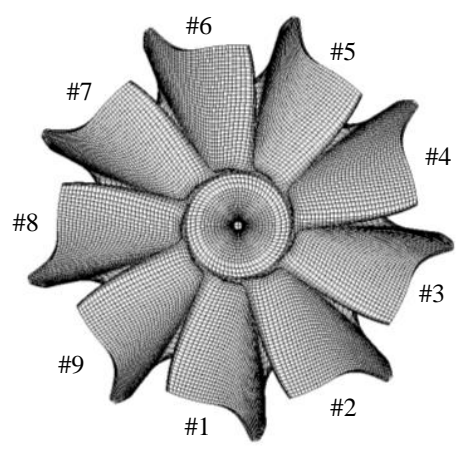

(a) FEM model

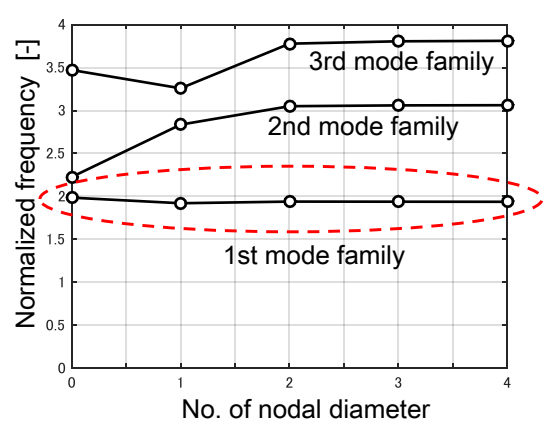

(b) Natural frequency of tuned system

Fig. 1 FEM model and natural frequency of tuned system. The number of grid points of the FEM model is around 14,000 per one segment and the total number of grid points of the whole model is around 120,000. In this study, the frequency response of the 1st mode family is examined in detail, assuming the resonance caused by the flow distortion.

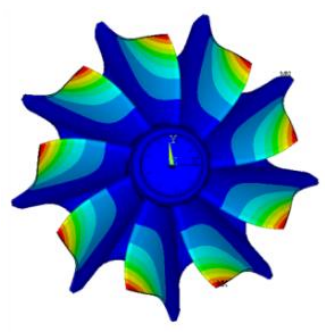

(a) $0 \mathrm{ND}$

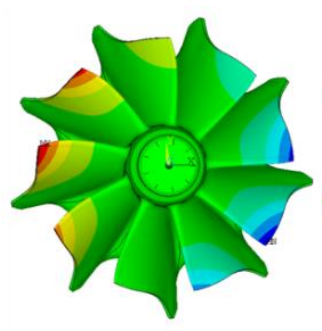

(b) $1 \mathrm{ND}$

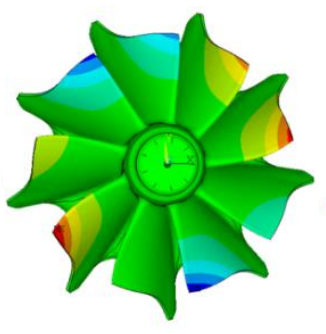

(c) $2 \mathrm{ND}$

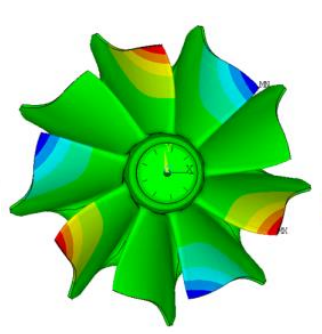

(d) $3 \mathrm{ND}$

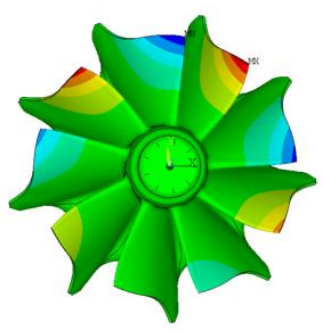

(e) $4 \mathrm{ND}$

Fig. 2 Typical vibration modes of tuned system (1st mode family). In the tuned system, the vibration modes show the periodicity. In the frequency response of the mistuned system, the natural frequency and the vibration mode of the tuned system calculated by FEM are used as input data to the FMM.

図 3 から図 5 に，\#1 翼と\#3 翼の振動数だけを変化させた Case 1 の解析結果を示す. 図 3 は Case 1 の振動モー ドであり，図 2 との比較から分かるように，ミスチューンの影響により振動モードの周期性が喪失し，振動モー ドの局在化（特定の翼の振幅だけが大きくなる現象）が発生している.

図 4 （a）はFMMによる周波数応答解析結果を，図４（b）は有限要素法で直接解析した周波数応答解析結果を 示している. 図 4 には，全周 9 枚の翼先端部の応答（振幅最大位置の応答）を重ね書きしており，縦軸はチュー ン系の共振振幅（共振条件を満たす 4 節直径モードの共振振幅）で正規化している.チューン系であれば全ての 翼の応答は同一になるが，図 4 から分かるように，ミスチューンの影響により個々の翼の応答に差が現われ，最 大振幅はチューン系よりも大きくなっている。また，FMM による解析結果と有限要素法による解析結果は，良 く一致している. 図 5 は, 図 4 の周波数志答解析結果から得られた各翼の最大振幅について, FMM で解析した 結果（○をつないだ黒の実線）と有限要素法で解析した結果（○）を比較している．図５に示すように，個々の 翼に発生する最大振幅についても, FMM による解析結果と有限要素法による解析結果は良く一致している. 


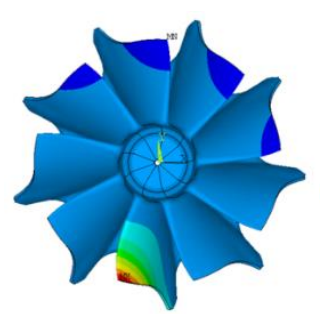

(a) $1 \mathrm{st}$

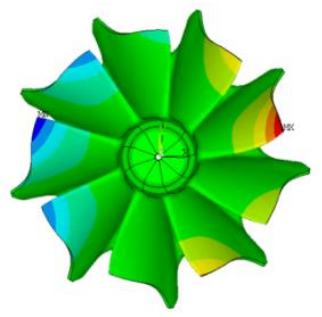

(b) 2nd

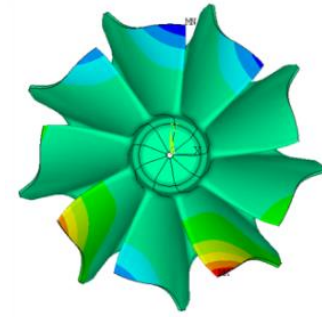

(c) 3rd

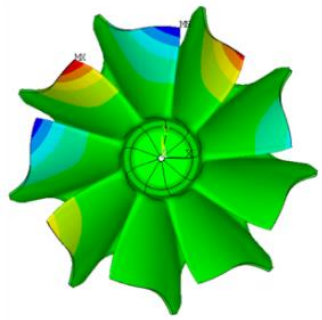

(d) 4 th

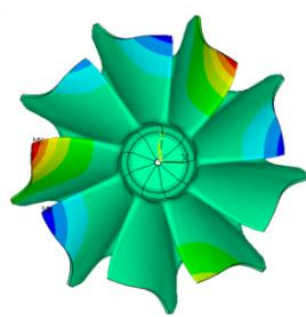

(e) 5 th

Fig. 3 Typical vibration modes of mistuned system (Case 1). In the mistuned system, the duplicated eigenvalues split into two single eigenvalues and the periodicity of the vibration mode is lost. As a result, in the forced response of a mistuned system, the responses of all blades become different, and the response of a certain blade may become extremely large.

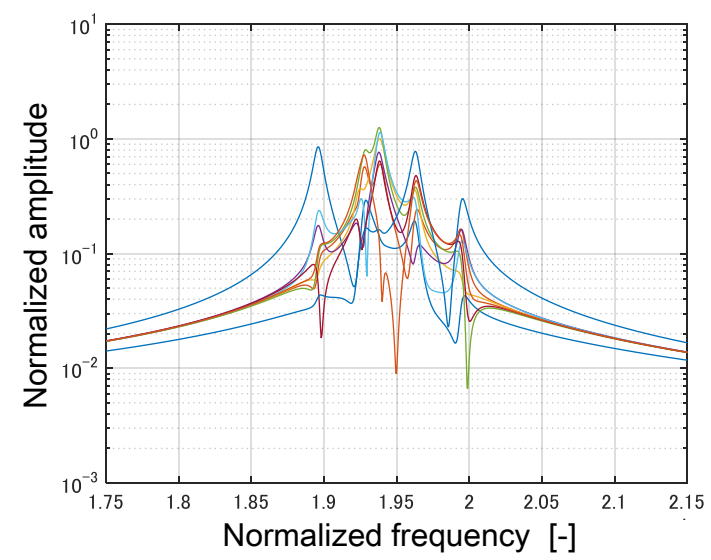

(a) FMM

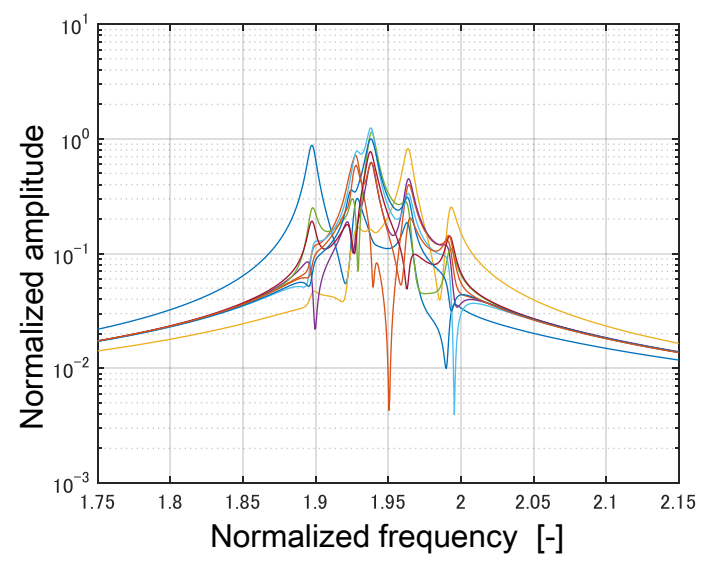

(b) FEM

Fig. 4 Frequency response of mistuned system (Case $1, H=5, \delta=0.01$ ). In case 1, the natural frequency of the No. 1 blade is changed by $-2 \%$, and the natural frequency of the No. 3 blade is changed by $+2 \%$. In the mistuned system, the responses of all blades become different. The frequency response of the mistuned system calculated by the FMM is consistent with that by FEM.

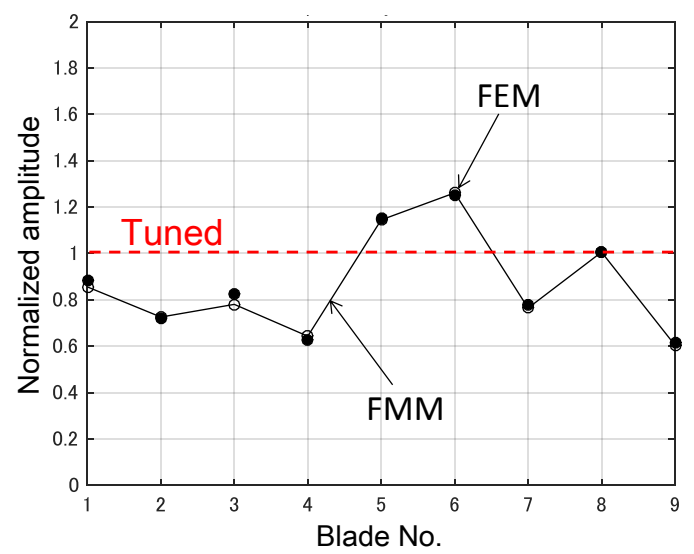

Fig. 5 Maximum amplitude of mistuned system (Case 1). The maximum amplitude of each blade in the mistuned system is obtained by the frequency response shown in Fig. 4. The maximum amplitude of each blade calculated by the FMM is also consistent with that by FEM.

図 6 から図 9 に, Case 2（ワーストミスチューン系）の解析結果を示す. 図 6 (a) は, 個々の翼の固有振動数 の変動が正規分布（変動係数 1\%）に従うと仮定し，FMM とモンテカルロ法（解析回数 10,000 回）で求めた各翼 に生じる最大振幅のヒストグラムであり，図 6 （b）はワーストミスチューン系（発生最大振幅 1.7）の振動数分 布を示している。図 7 は, ワーストミスチューン系の振動モードであり, Case 1 と同様に, ミスチューンの影響 
により振動モードの周期性が喪失し，振動モードの局在化（特定の翼の振幅だけが大きくなる現象）が発生して いる. 図 8 (a) は FMMによる周波数応答解析結果を, 図 8 (b) は有限要素法で直接解析した周波数応答解析結 果を示している. また，図 9 は，図 8 の周波数応答解析結果から得られた各翼の最大振幅について，FMM で解 析した結果と有限要素法で解析した結果を比較している. 図 8 や図 9 から分かるように，ワーストミスチューン 系についても，FMMによる解析結果と有限要素法による解析結果は良く一致している.

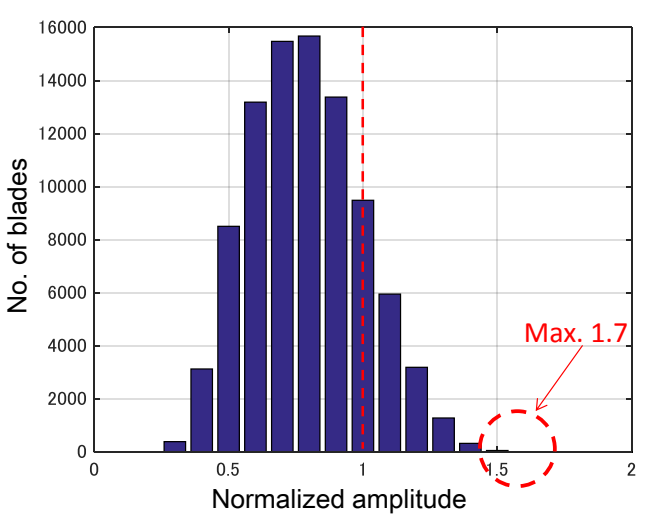

(a) Histogram of resonant amplitude $\left(\sigma_{f}=1 \%\right)$

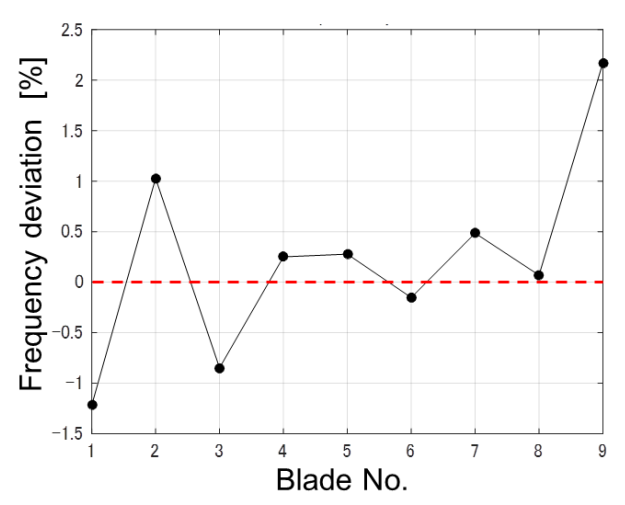

(b) Frequency deviation of the worst mistuned system

Fig. 6 Histogram of resonant amplitude of randomly mistuned system and frequency deviation of the worst mistuned system (Case $2, H=5, \delta=0.01$ ). The maximum amplitude and the mistuning distribution (the frequency deviation of each blade) of the worst mistuned system is calculated by the Monte Carlo simulation, where 10,000 calculations were repeated, assuming that the distribution of the blade alone frequency follows a normal distribution given. In the worst mistuned system, the maximum amplitude becomes 1.7 times larger than that of the tuned system.

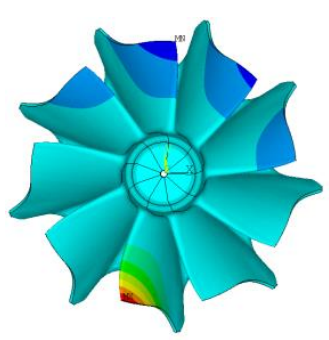

(a) $1 \mathrm{st}$

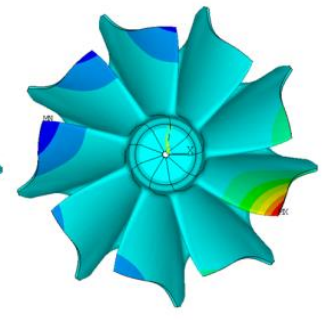

(b) 2nd

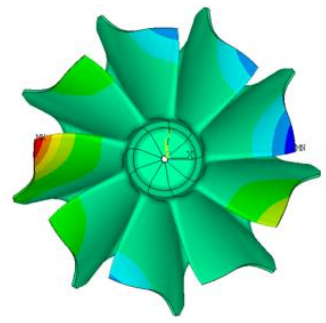

(c) $3 \mathrm{rd}$

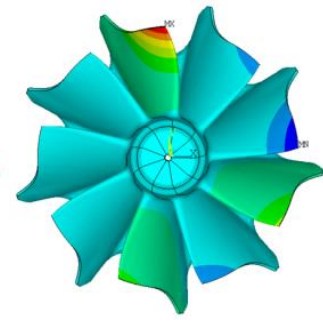

(d) 4 th

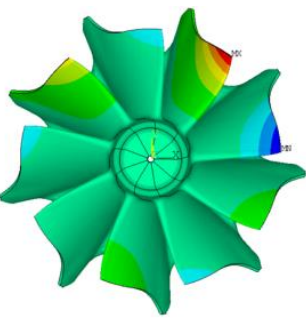

(e) 5 th

Fig. 7 Typical vibration modes of the worst mistuned system (Case 2). Also in the worst mistuned system of case 2, the duplicated eigenvalues split into two single eigenvalues and the periodicity of the vibration mode is lost. As a result, in the forced response of a mistuned system, the responses of all blades become different, and the response of a certain blade may become extremely large. 


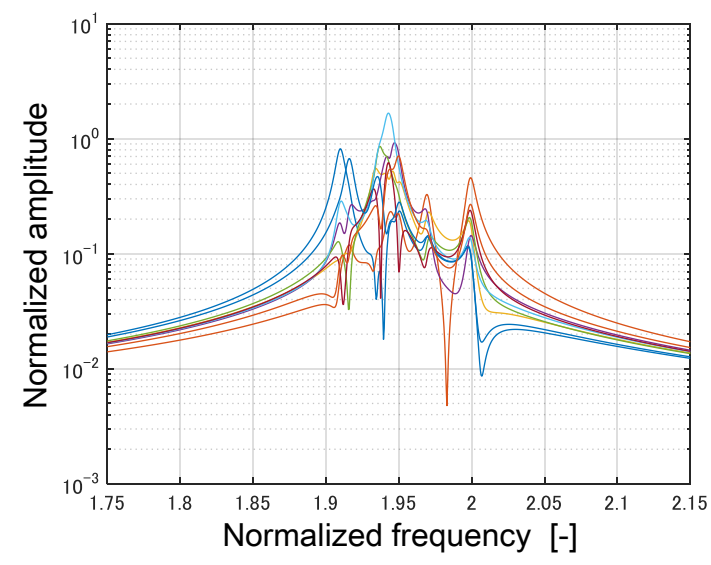

(a) FMM

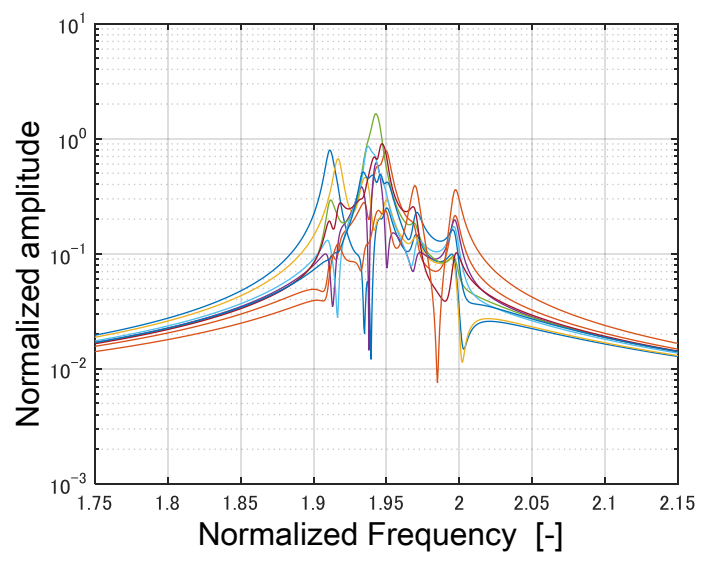

(b) FEM

Fig. 8 Frequency response of mistuned system (Case $2, H=5, \delta=0.01$ ). In the worst mistuned system, the responses of all blades become different. The frequency response of the worst mistuned system calculated by the FMM is consistent with that by FEM.

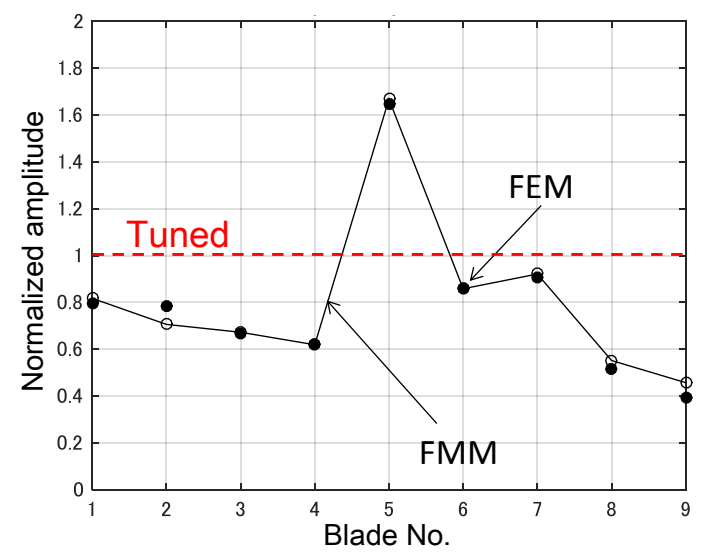

Fig. 9 Maximum amplitude of mistuned system (Case 2). The maximum amplitude of each blade in the worst mistuned system is obtained by the frequency response shown in Fig. 8. The maximum amplitude of each blade calculated by the FMM is also consistent with that by FEM.

\section{$3 \cdot 2$ タービン動翼の共振応答の変動解析}

3 ・ 1 節の検証計算結果から, FMM を適用すれば有限要素法と同程度の精度で効率良くミスチューン系の解析 ができることが確認できたため，ミスチューン系に発生する共振応答の変動を解析した．図 10 には：ミスチュー ン系の共振応答の変動を評価するためのパラメータを示している. ミスチューン系の共振応答の変動は，チュー ン系の共振振幅で正規化した最大振幅, 全翼の共振応答の平均值, 全翼の共振応答の変動係数, および共振回避 振動数範囲 $\left(\Delta f_{r e s}\right)$ で評価している．共振回避振動数範囲は，発生する振幅がチューン系の共振振幅の $1 / \sqrt{2}$ を 超える加振周波数の範囲と定義している.

図 11 （a）は，各翼の振動数の変動が正規分布に従うと仮定し，FMM とモンテカルロ法（解析回数 10,000 回） により, 各翼の振動数の変動係数とタービン動翼に発生する共振応答の最大值, 平均值, 変動係数を求めた結果 を示している. また，図 11 (b) は，各翼の振動数の変動係数と共振回避振動数範囲の関係を示している. 図 11

(a) に示すように, 翼振動数の変動係数が大きくなると, 発生する共振応答の最大值は急激に増加し, 翼振動数 の変動係数が約 $1 \%$ ときにその最大值（約 1.7）に達した後, 漸減する傾向を示している. 一方, 共振回避振動 
数範囲は, 翼振動数の変動係数の増加に比例して, 単調に増加している. 解析したタービン動翼はシュラウドが ない単独翼構造であり，周方向の連成が小さいためミスチューンに対して敏感であることが示されている.

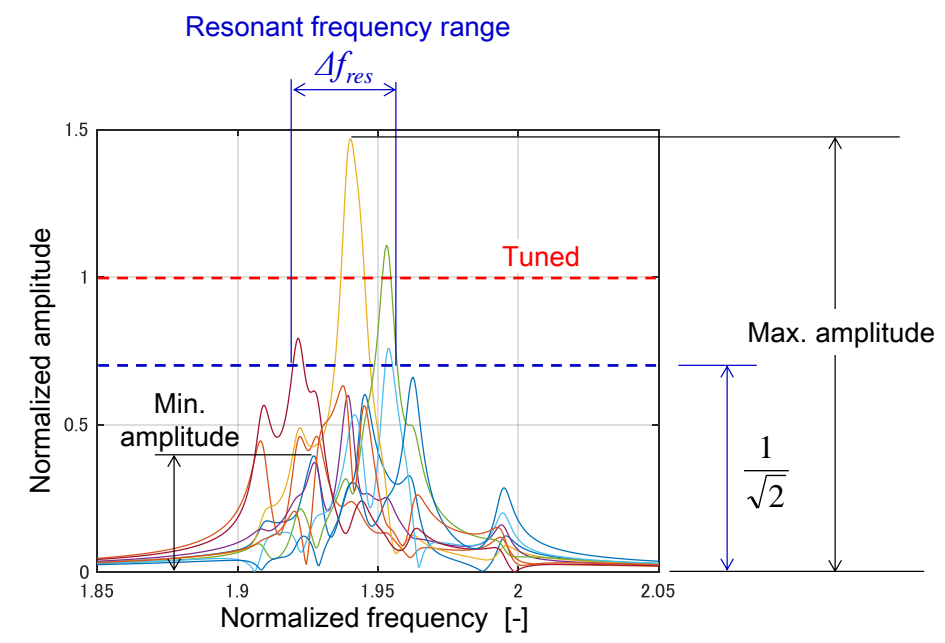

Fig. 10 Parameters for evaluating the vibration response characteristics of mistuned system. The mistuning effect is evaluated by the maximum amplitude, the mean value and the standard deviation of amplitudes of all blades. The resonant frequency range $\Delta f_{\text {res }}$ is defined as an excitation frequency range, in which the vibration response exceeds the resonant amplitude of the tuned system divided by $\sqrt{2}$.

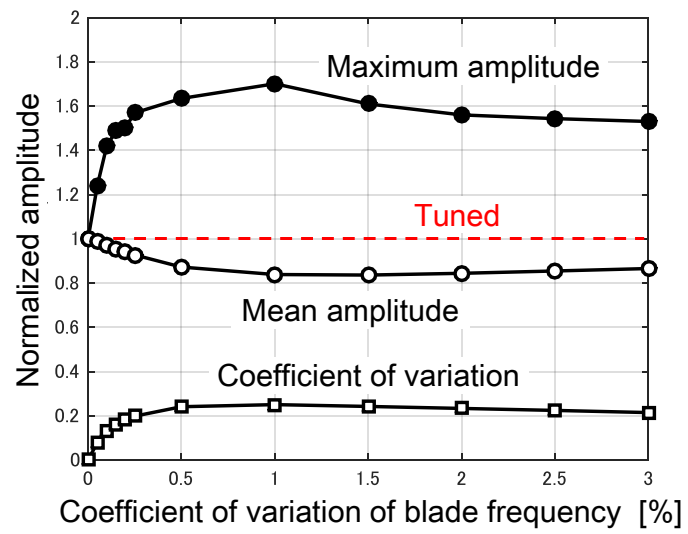

(a) Amplitude

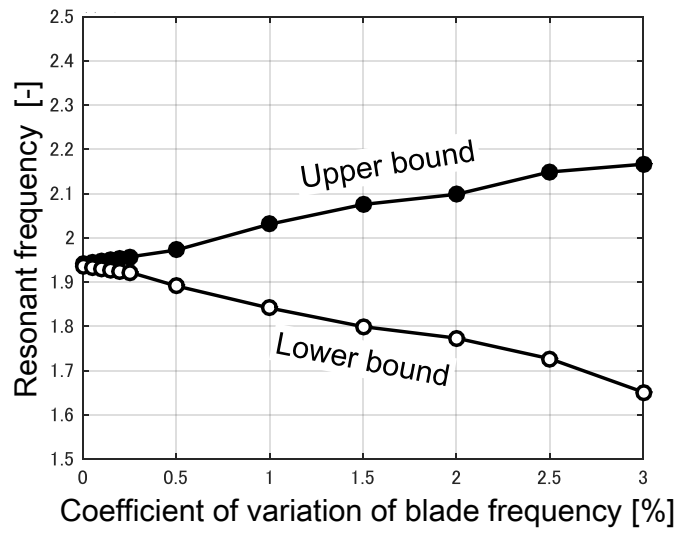

(b) Resonant frequency range

Fig. 11 Amplitude and resonant frequency range of mistuned system $(H=5, \delta=0.01)$. The maximum amplitude of the randomly mistuned system increases rapidly with the coefficient of variation of the blade frequency $\sigma_{f}$ and then gradually decreases after reaching a maximum around $\sigma_{f}=1 \%$. The maximum amplitude of the randomly mistuned system becomes 1.7 times larger than that of the tuned system. The resonant frequency range is also widened as $\sigma_{f}$ increases.

図 12 (a) は翼振動数の変動係数を $1 \%$ に固定し, タービン動翼の対数減衰率をパラメータにしてモンテカルロ 法で共振応答の最大值，平均值，変動係数を求めた結果を示している．図 12 (a) 中には，FMM と Matlab の制 約なし最適化アルゴリズム (fminsearch) を使用して共振応答の最大值を求めた結果を赤丸で記入している.また, Keynon らが導出した共振応答の最大值の理論值, すなわち式 (10) で定義される Keynon 係数 (Keynon and Griffin,

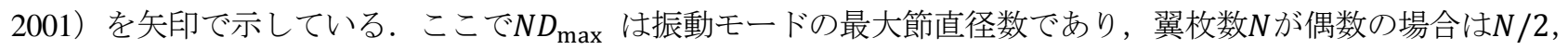
奇数の場合は $(N-1) / 2$ あるる. 一方, 図 12 (b) は, タービン動翼の対数減衰率と共振回避振動数範囲の関係を 示している.これから分かるように，タービン動翼の減衰を変化させても共振応答の最大值や共振回避振動数範 囲はほとんど変化しない. また, モンテカルロ法で求めた共振応答の最大值は, 最適化アルゴリズム (fminsearch) で求めた最大值や Keynon 係数とほぼ一致している. 
$\gamma=\frac{1+\sqrt{1+N D_{\max }}}{2}$

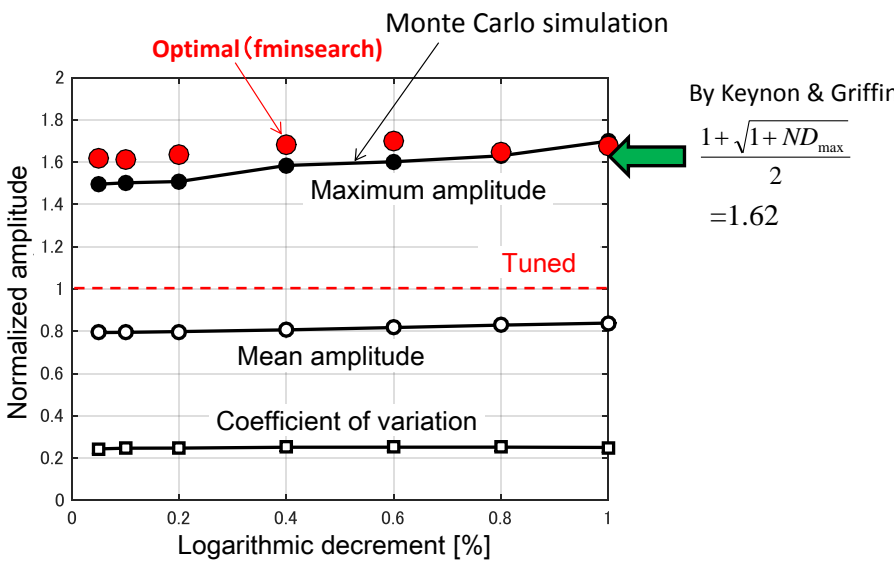

(a) Amplitude

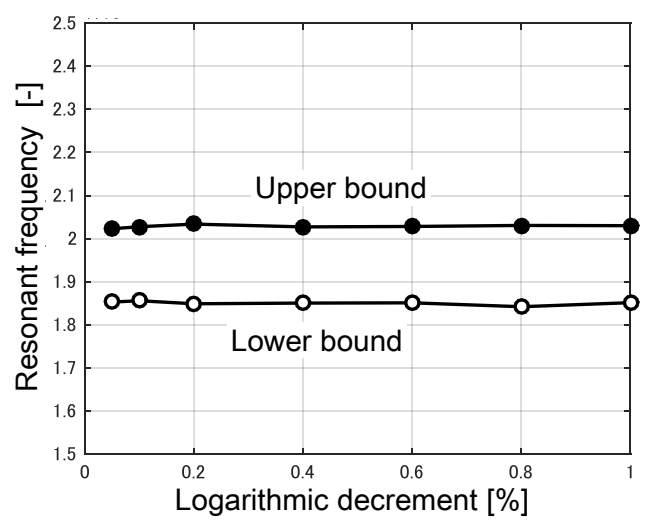

(b) Resonant frequency range

Fig. 12 Amplitude and resonant frequency range of mistuned system $\left(H=5, \sigma_{f}=1 \%\right)$. The effect of the damping on the amplification factor and the resonant frequency range is small. The amplification factor and the resonant frequency range hardly change if the logarithmic decrement changes from $0.05 \%$ to $1 \%$. The amplification factor calculated by the Monte Carlo simulation is nearly the same as one calculated by the optimal algorithm of Matlab.

図 13 (a) は加振力のハーモニック数を $H=3$ に変更して, FMM とモンテカルロ法（解析回数 10,000 回）によ り，各翼の振動数の変動係数とタービン動翼に発生する共振応答の最大值，平均值，変動係数を求めた結果を示 している. また，図 13 (b) は, 各翼の振動数の変動係数と共振回避振動数範囲の関係を示している. 図 11（H=5） と図 $13(H=3)$ の比較から分かるように，解析したタービン動翼については加振力のハーモニック数がミスチュ ーン系の応答特性に及ぼす影響は小さく，何れの場合も翼振動数の変動係数が約 $1 \%$ ときに共振応答の最大值

（約 1.7）に達しており，マクロに見れば同一の特性を示している.

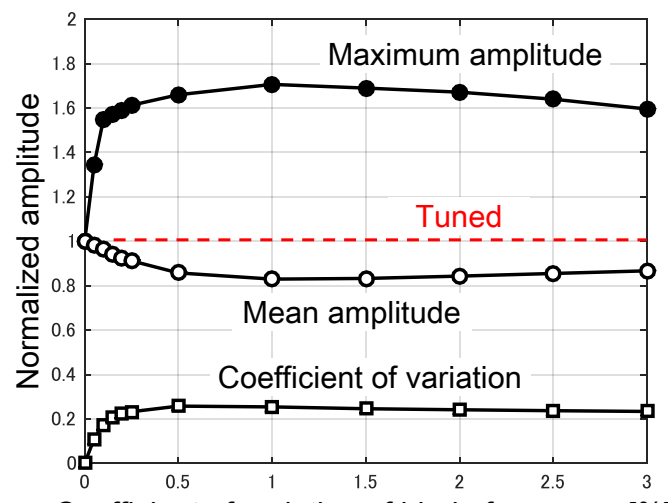

Coefficient of variation of blade frequency [\%]

(a) Amplitude

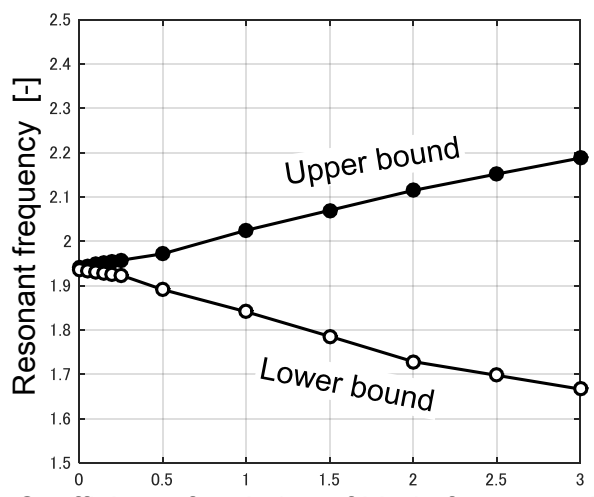

Coefficient of variation of blade frequency [\%]

(b) Resonant frequency range

Fig. 13 Amplitude and resonant frequency range of mistuned system $(H=3, \delta=0.01)$. For the frequency response to $H=3$, the mistuning effect is almost the same as that for $H=5$ shown in Fig. 11. Namely, the maximum amplitude increases rapidly with the coefficient of variation of the blade frequency $\sigma_{f}$ and then gradually decreases after reaching the maximum around $\sigma_{f}=1 \%$. The maximum amplitude of the randomly mistuned system becomes 1.7 times larger than that of the tuned system. The resonant frequency range is also widened as $\sigma_{f}$ increases. 
図 14 は, タービン動翼の翼枚数をパラメータにして, FMM と Matlab の制約なし最適化アルゴリズム (fminsearch) を使用して共振応答の最大值を求めた結果を示しており, 図中には Keynon 係数もプロットしている. なお, 翼 枚数を変更して共振応答を計算する場合は, 翼枚数が 9 枚のときの振動モードの節直径数と振動数の関係（図 14

(b) ) の横軸をスケーリングして $N=9$ 以外の振動モードの節直径数と振動数の関係を図 14 (c) のように作成し, これを FMM に入力して周波数応答解析を計算している. 例えば, 翼枚数が 15 枚の場合は， 0 節直径モード， 1 節直径モード，および節直径数が最大 $\left(n_{\max }=(N-1) / 2\right)$ のモードの振動数は翼枚数が 9 枚の場合と 15 枚の場合で 同一と仮定し，2 節直径から $n_{\text {max }}-1$ （翼枚数が 15 の場合は $n_{\text {max }}-1=6$ ）節直径モードまでの振動数は，図 14 (b) の最大節直径数 $n_{\max }$ を 4 から 7 に変更した図から内挿して求めている.

図 14 （a）に示すように，翼枚数が増加すると，共振応答の最大值は漸増する傾向を示しており，fminsearchで 求めた最大值の増加傾向は Keynon 係数の増加傾向とほぼ対応している.

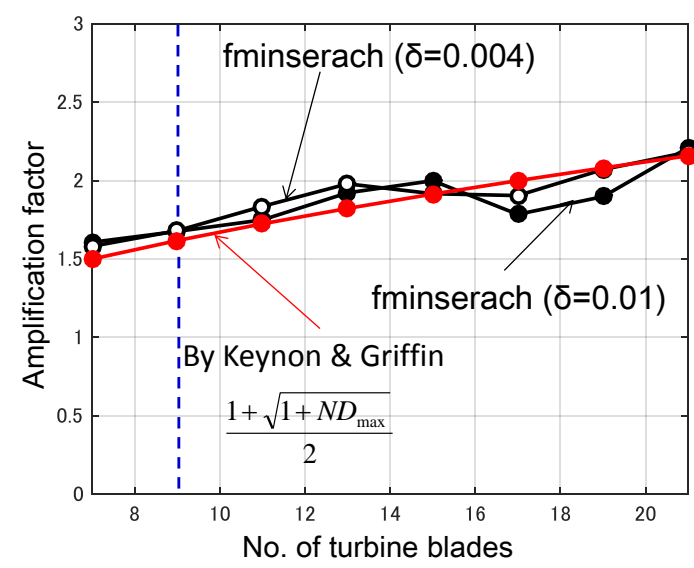

(a) Maximum amplitude

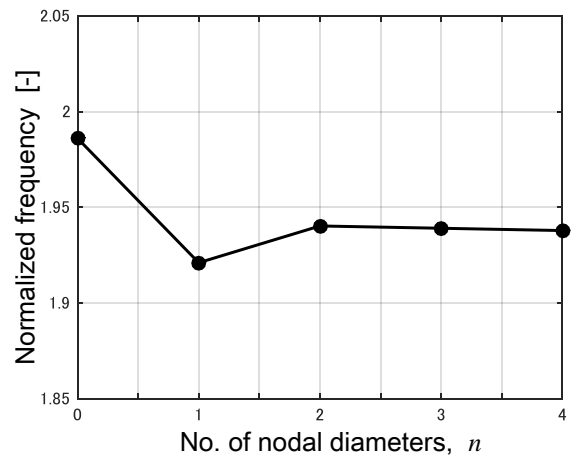

(b) Natural frequency $(N=9)$

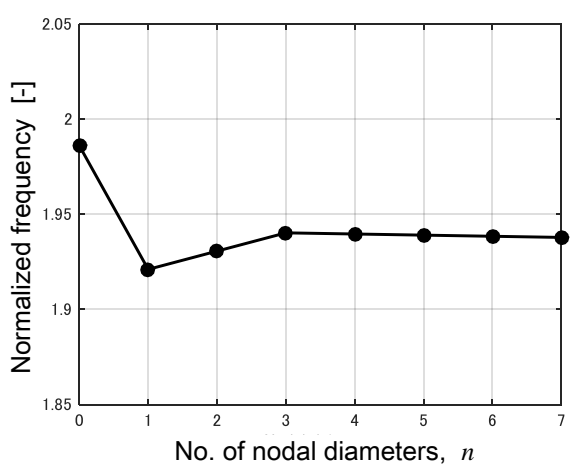

(c) Natural frequency $(N=15)$

Fig. 14 Relation of the blade count and the maximum amplitude $(H=5)$. In the parametric study on the blade count of a turbine blade, the natural frequency of the turbine blade is estimated by scaling the number of the nodal diameters of the vibration modes as shown in Fig. 14(b) and Fig. 14(c). With increase of the blade count the maximum amplification factor increases. This tendency is consistent with Keynon's theory.

\section{$3 \cdot 3$ インテンショナルミスチューンによる共振応答低減}

$3 \cdot 2$ 節で説明したように, 鋳造条件の差異などによりヤング率の変動 (ランダムミスチューン) が発生すると, タービン動翼に発生する共振振幅の最大值はチューン系の 1.7 倍程度まで増大し得る.このようなランダムミス チューンにより発生する共振応答の増大効果を緩和する手法として, インテンショナルミスチューンが有効であ ることが指摘されている (Han et al., 2014)。すなわち，インテンショナルミスチューンでは，共振応答の最大值 を低減できるように明瞭なミスチューンを与えてタービン動翼を設計しておき，製造時に生じるランダムミスチ 
ユーンの影響を緩和寸る，本研究では，実機への適用性を考慮し，以下の手順でターボチャージャ用タービン動 翼に対するインテンショナルミスチューンの共振応答低減効果を検証した.

(1) 2 種類の翼（平均值より振動数が $3 \%$ 高い $\mathrm{H}$ 翼, 平均值より振動数が $3 \%$ 低い $\mathrm{L}$ 翼) で構成されるタービン 動翼に対して，遺伝的アルゴリズムを改良した最適化手法 DDE（北山他，2010）を利用し，インテンショナル ミスチューン系 (共振応力が最小になる $\mathrm{L}$ 翼と $\mathrm{H}$ 翼の配列) を求める．なお，実際の翼の振動強度設計では， フローパターンにマッチングするオリジナルの翼型を設計した後, 性能に影響を与えない範囲でオリジナルの 翼型から翼形状のパラメータ（各断面の最大肉厚, 最大肉厚位置, インシデンスなど）を微調整して固有振動 数の調整を行っている（金子他，1991）。従って， $\pm 3 \%$ 程度の固有振動数の変更であれば，翼形状のパラメー 夕を微調整することにより，容易に実現可能と考えられる.

(2) インテンショナルミスチューン系にランダムミスチューンを重畳させ, チューン系にランダムミスチューン が重畳した場合（図 11）から, どの程度共振応答を低減できるかを検証する.

図 15 は, DDE で求めた共振応答が最小になるインテンショナルミスチューン系の各翼の振動数分布を示して いる. 図 16 (a) は，図15 のインテンショナルミスチューン系の周波数応答解析結果であり，図 16 (b) は各翼 に発生する共振応答の最大值を示している。これから分かるように，インテンショナルミスチューン系では，共 振応答の最大值はチューン系の 0.89 倍に低減できる.

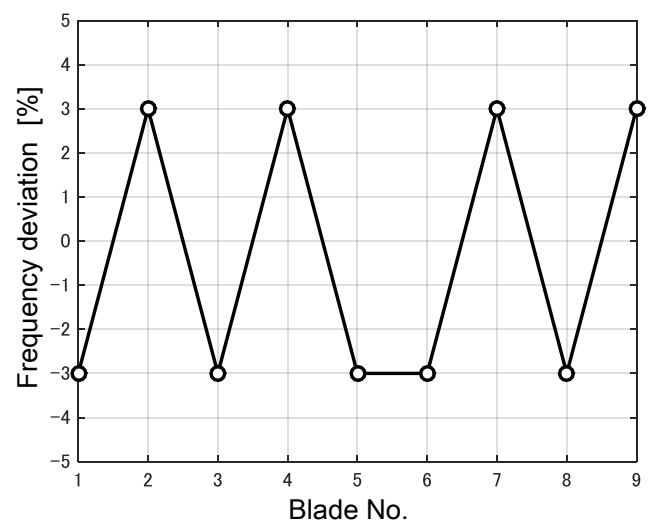

Fig. 15 Frequency deviation of intentionally mistuned system. The intentional mistune distribution shown in Fig. 15 is obtained by the optimal algorithm DDE (Discrete Differential Evolution) assuming that the turbine wheel consists of just two kinds of blades. One of blades is $\mathrm{H}$ blade with the higher frequency by $3 \%$, and another blade is $\mathrm{L}$ blade with the lower frequency by $-3 \%$.

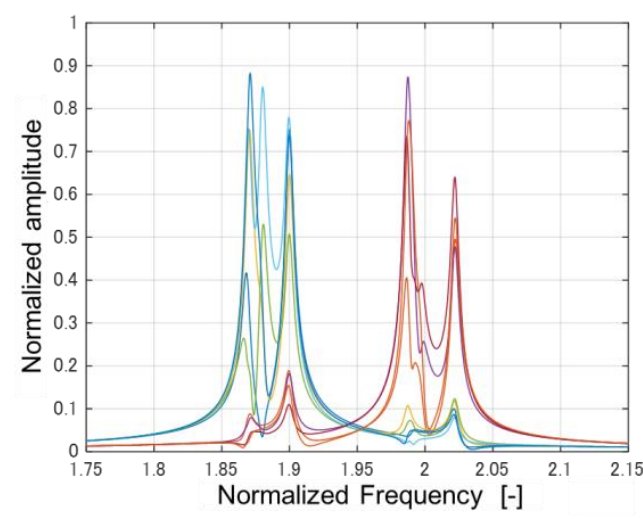

(a) Frequency response

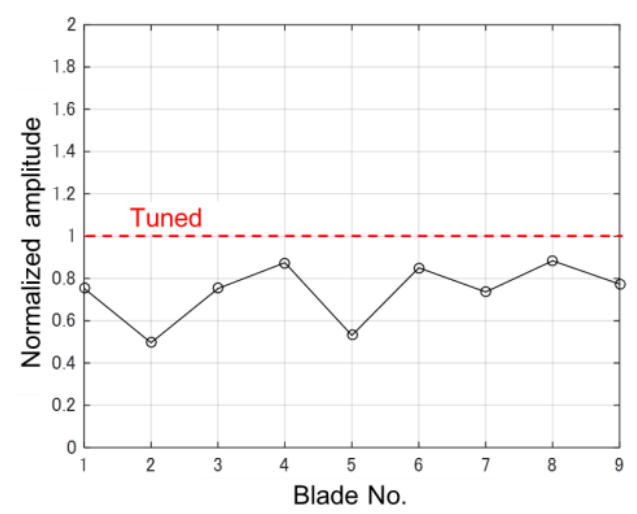

(b) Maximum amplitude

Fig. 16 Frequency response and the maximum amplitude of intentionally mistuned system $(H=5, \delta=0.01)$. In the frequency response of the intentionally mistuned system without random mistune, the maximum amplitude can be suppressed to 0.89 times of that of the tuned system. 
図 17 (a) は，図 15 のインテンショナルミスチューン系にランダムミスチューンを重畳させたタービン動翼の 共振応答特性を示しており, 各翼の振動数の変動係数（ランダムミスチューンの変動係数）とタービン動翼に発 生する共振応答の最大值，平均值，変動係数を求めた結果を示している．また図 17 (a) には，チューン系にラ ンダムミスチューンを重畳させたときの特性（図 11）も重ね書きしている. 図 17 (a) に示すように，現実的な ランダムミスチューン (変動係数が $1 \%$ 程度) であれば, インテンショナルミスチューンを採用することにより， 共振応答の最大值を 1.7 から 1.4 程度まで低減できることが示されている. ランダムミスチューンの変動係数が $2 \%$ 以上なると, ランダムミスチューンの変動とインテンショナルミスチューンの変動が同程度になるため, イ ンテンショナルミスチューンの共振応答低減効果は喪失するが, ランダムミスチューンの変動係数が $2 \%$ 以に なっても改悪にはならない. 図 17 （b）は, 各翼の振動数の変動係数（ランダムミスチューンの変動係数）と共 振回避振動数範囲を示している. インテンショナルミスチューンを採用すると, 共振回避振動数範囲は, チュー ン系にランダムミスチューンを重畳させたときよりも拡大する.このため，インテンショナルミスチューンを採 用する場合には，共振応答の低減効果と同時に共振振動数範囲の拡大を考慮することが必要である.

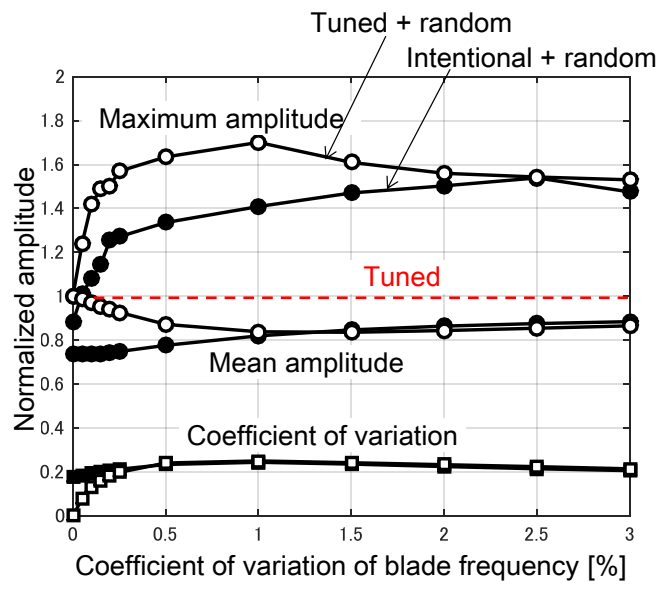

(a) Amplitude

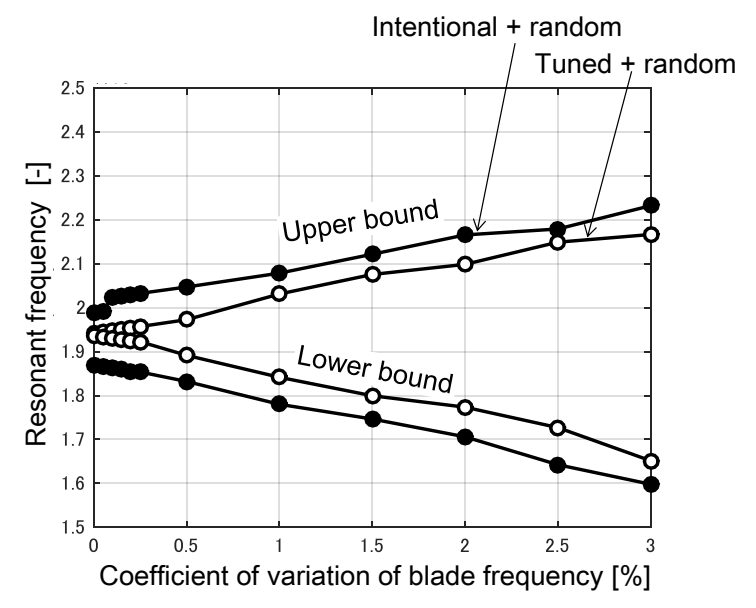

(b) Resonant frequency range

Fig. 17 Amplitude and resonant frequency range of intentionally mistuned system $(H=5, \delta=0.01)$. In the intentionally mistuned system superposing the random mistune, the maximum amplitude can be suppressed until the coefficient of variation of the blade frequency caused by the random mistune increases up to around $2 \%$. For the realistic coefficient of variation of the blade frequency of around 1\%, the maximum amplification factor can be reduced to 1.4 from 1.7 of the randomly mistuned system. On the other hand, the resonant frequency range becomes wider than that of the randomly mistuned system.

\section{4. 結 論}

本論文では, ターボチャージャ用のタービン動翼に対して低次元モデル FMM を利用し，強制振動に対するタ 一ビン動翼のミスチューン特性を調査した。 またタービン動翼の実用的な振動応答低減手法として，インテンシ ヨナルミスチューン系の共振応答低減効果を検討した。 その結果，以下の結論が得られた.

（1）翼枚数が少ないターボチャージャ用のタービン動翼に対しても，FMM の解析結果と有限要素法で直接解析 した結果は良く一致する.

(2) 解析したタービン動翼はシュラウドがない単独翼構造であり, 周方向の連成が小さいためミスチューンに対 して敏感であり，共振応答の最大值はチューン系の 1.7 倍程度まで増加する.

（3）ミスチューン系の応答特性（発生最大振幅, 共振回避振動数範囲）は, タービン動翼の減衰や加振力のハー モニック数を変えてもほとんど変化しない.

(4) タービン動翼の翼枚数を変更するとミスチューン系に発生する共振応答の最大值は単調に増加し, 増加の傾 向は Keynon 係数とほぼ一致する. 
（5）インテンショナルミスチューンを採用すると，現実的なランダムミスチューン（変動係数が $1 \%$ 程度）に対 しては, 発生する共振応答の最大值を 1.7 から 1.4 まで低減できる. ただし, 共振回避振動数範囲は拡大寸る ため，共振応答の低減効果と同時に共振振動数範囲の拡大を考慮することが必要である.

\section{文献}

Feiner, D. M. and Griffin, J. H., A fundamental model of mistuning for a single family of modes, ASME, Journal of Turbomachinery, Vol.124 (2002), pp.597-605.

Feiner, D. M. and Griffin, J. H., Mistuning identification of bladed disks using a fundamental mistuning model-part 1: theory, Proceedings of ASME Turbo Expo 2003, GT2003-38952 (2003), pp.1-10.

Han, Y., Murthy, R., Mignolet, M. P. and Lentz, J., Optimization of intentional mistuning patterns for the mitigation of the effects of random mistuning, ASME Journal of Engineering for Gas Turbines and Powers, Vol. 136 (2014), pp.1-9.

Hemberger, D., Filsinger, D. and Bauer, H-J., Mistuning modeling and its validation for small turbine wheels, Proceedings of ASME Turbo Expo 2013, GT2013-94019 (2013), pp.1-8.

Hemberger, D., Filsinger, D. and Bauer, H-J., Identification of mistuning for casted turbine wheels of small size, Proceedings of ASME Turbo Expo 2014, GT2014-25099 (2014), pp.1-8.

金子康智, 間瀬正隆, 藤田勝久, 感度解析法によるタービン翼の最適設計, 日本機械学会論文集 C 編, Vol. 57, No. 541 (1991), pp.2965-2970.

金子康智，中西亮太，森一石，大山宏治，ミスチューンがある翼・ディスク系の振動特性に関する研究（低次元 モデル FMM による振動応答解析)，日本機械学会論文集 C 編，Vol. 79, No. 801 (2013), pp.1372-1385.

金子康智，渡邊敏生，前田茂稔，熟尾宰司，ミスチューンを有する翼・ディスク系の振動応答に関する研究（応 力で評価した高次モードのミスチューン特性），日本機械学会論文集，Vol. 83，No. 855 (2017), DOI:10.1299/transjsme.17-00184.

北山哲士，荒川雅生，山崎光悦，Discrete Differential Evolution の提案，日本機械学会論文集 C 編，Vol. 76, No. 772 (2010), pp.3828-3836.

Keynon, J. A. and Griffin J. H., Forced response of turbine engine bladed disks and sensitivity to harmonic mistuning, Proceedings of ASME Turbo Expo 2001, 2001-GT-0274 (2001), pp.1-10.

宮下和也，自動車用過給機ラジアルタービン翼振動に関する技術動向（第 3 報 : 振動特性の影響要因），ターボ機 械, Vol. 45, No.2 (2017), pp.65-74.

大迫雄志，陣内靖明，佐俣章，鈴木浩，茨木誠一，林慎之，自動車用高性能・高信頼性 VG ターボチャージャの 開発，三菱重工技報，Vol. 43, No.3 (2006), pp.31-35.

\section{References}

Feiner, D. M. and Griffin, J. H., A fundamental model of mistuning for a single family of modes, ASME, Journal of Turbomachinery, Vol.124 (2002), pp.597-605.

Feiner, D. M. and Griffin, J. H., Mistuning identification of bladed disks using a fundamental mistuning model-part 1: theory, Proceedings of ASME Turbo Expo 2003, GT2003-38952 (2003), pp.1-10.

Han, Y., Murthy, R., Mignolet, M. P. and Lentz, J., Optimization of intentional mistuning patterns for the mitigation of the effects of random mistuning, ASME Journal of Engineering for Gas Turbines and Powers, Vol. 136 (2014), pp.1-9.

Hemberger, D., Filsinger, D. and Bauer, H-J., Mistuning modeling and its validation for small turbine wheels, Proceedings of ASME Turbo Expo 2013, GT2013-94019 (2013), pp.1-8.

Hemberger, D., Filsinger, D. and Bauer, H-J., Identification of mistuning for casted turbine wheels of small size, Proceedings of ASME Turbo Expo 2014, GT2014-25099 (2014), pp.1-8.

Kaneko, Y., Mase, M. and Fujita K., Optimal design of turbine blade by sensitivity analysis, Transactions of the Japan Society of Mechanical Engineers, Series C, Vol. 57, No. 541 (1991), pp.2965-2970 (in Japanese).

Kaneko, Y., Nakanishi, Y., Mori, K. and Ooyama, H., Study on vibration characteristics of mistuned bladed disk (Vibration response analysis by reduced model FMM), Transactions of the Japan Society of Mechanical Engineers, Series C, Vol. 79, No. 801 (2013), pp.1372-1385 (in Japanese). 
Kaneko, Y., Watanabe, T., Maeda, S. and Washio, S., Study on vibration response characteristics of mistuned bladed disk (Mistuning Phenomena of higher modes evaluated by vibratory stress), Transactions of the JSME (in Japanese), Vol.83, No. 855 (2017), DOI:10.1299/transjsme.17-00184.

Kitayama, S., Arakawa, M. and Yamazaki, K., Proposal of discrete differential evolution, Transactions of the Japan Society of Mechanical Engineers, Series C, Vol. 76, No. 772 (2010), pp.3828-3836 (in Japanese).

Keynon, J. A. and Griffin J. H., Forced response of turbine engine bladed disks and sensitivity to harmonic mistuning, Proceedings of ASME Turbo Expo 2001, 2001-GT-0274 (2001), pp.1-10.

Miyasita, K., Recent trend of radial turbine blade vibration of automotive turbocharger (3rd report: Various factors affecting vibration characteristics), Turbomachinery, Vol. 45, No.2 (2017), pp.65-74 (in Japanese).

Osako, K., Jinnai, Y., Samata, A., Suzuki, H., Ibaraki, S. and Hayashi, N., Development of the high performance and high reliability VG turbocharger for the automotive, Mitsubishi Heavy Industries Technical Review, Vol. 43, No.3 (2006), pp.31-35 (in Japanese). 